Uniwersytet PrzyrodniczoHumanistyczny w Siedlcach

Siedlce University of Natural Sciences and Humanities

https://bazawiedzy.uph.edu.pl

\begin{tabular}{|l|l|}
\hline Publikacja / Publication & $\begin{array}{l}\text { Virulence factors and ability of staphylococci from bovine milk and the cowshed } \\
\text { environment to biofilm formation, } \\
\text { Kot Barbara, Binek Tomasz, Piechota Małgorzata, Wolska Marzena Katarzyna, } \\
\text { Zdunek Ewa, Płatkowska Kamila }\end{array}$ \\
\hline $\begin{array}{l}\text { Adres publikacji w Repozytorium URL } \\
\text { / Publication address in Repository }\end{array}$ & https://bazawiedzy.uph.edu.pl/info/article/UPHfdc0217e3bce46b6a641ebcd5ba15fc9/ \\
\hline $\begin{array}{l}\text { Data opublikowania w Repozytorium / } \\
\text { Deposited in Repository on }\end{array}$ & 22 paź 2021 \\
\hline Rodzaj licencji / Type of licence & Attribution CC BY O \\
\hline & $\begin{array}{l}\text { Kot Barbara, Binek Tomasz, Piechota Małgorzata, Wolska Marzena Katarzyna, } \\
\text { Zdunek Ewa, Płatkowska Kamila: Virulence factors and ability of staphylococci } \\
\text { from bovine milk and the cowshed environment to biofilm formation, Polish Journal } \\
\text { of Veterinary Sciences, vol. 16, no. 4, 2013, pp. 639-645 }\end{array}$ \\
\hline
\end{tabular}




\title{
Virulence factors and ability of staphylococci from bovine milk and the cowshed environment to biofilm formation
}

\author{
B. Kot, T. Binek, M. Piechota, K.M. Wolska, E. Zdunek, K. Płatkowska \\ Department of Microbiology, Institute of Biology, Siedlce University of Natural Sciences and Humanities, \\ Bolesława Prusa 12, 08-110 Siedlce, Poland
}

\begin{abstract}
The aim of this study was to examine virulence factors and the ability of $S$. aureus and CNS species isolated from milk of cows with mastitis to form biofilm, and to compare them with virulence factors of staphylococci from milk of cows without mastitis and cowshed environment. Most of $S$. aureus strains from cows with mastitis showed haemolytic activity (93.9\%), among them $72.7 \%$ and $21.2 \%$ produced $\alpha$ - and $\beta$-haemolysin, respectively. $S$. aureus from cows with mastitis symptoms produced proteases (above $48 \%$ ) and esterase (42.4\%). The highly significant relationship between the number of $S$. xylosus strains producing haemolysins $(62 \%)$ and the origin of these strains from milk of cows with mastitis was observed. The ability to produce proteases was significantly associated with $S$. sciuri from milk of cows with mastitis. The ability of biofilm formation by staphylococcal strains from milk of cows with mastitis was greater than in strains from milk of cows without mastitis and the difference was significant $(\mathrm{p} \leq 0.05)$. The highest percentage of strains from milk of cows with mastitis were weak biofilm formers (48.6\%), while $40 \%$ and $11.4 \%$ of strains were moderate and strong biofilm producers, respectively. S. xylosus showed the highest ability to form biofilm, while the lowest ability to form biofilm was observed in S. aureus and S. epidermidis.

In conclusion, production of exotoxins and enzymes, and ability of biofilm formation shown by many CNS isolated from milk of cows with mastitis symptoms indicates that these features are important in pathogenesis of this disease.
\end{abstract}

Key words: Staphylococcus aureus, coagulase-negative staphylococci, virulence factors, biofilm, mastitis

\section{Introduction}

Staphylococci are the most important pathogenic bacteria involved in all forms of bovine mastitis (Malinowski et al. 2006, Kot et al. 2012a,b, Simojoki et al. 2012). Staphylococcus aureus is regarded as a major pathogen of mastitis in the cattle (Vasudevan et al. 2003, Dhanawade et al. 2010). The pathogenesis of mastitis caused by $S$. aureus is the result of extracellular factors and production of toxins, together with adherence and biofilm formation. S. aureus isolated from cases of bovine mastitis produced haemolysins,

Correspondence to: B. Kot, e-mail: barbara.kot@uph.edu.pl, tel.: +48 256431339 
enterotoxins, leukocidins and coagulase (Hata et al. 2006, Peles et al. 2007, Capurro et al. 2010). $\alpha$-haemolysin has haemolytic, dermonecrotic and neurotoxic activity and is considered main pathogenicity factor of $S$. aureus (Dinges et al. 2000). $\beta$-haemolysin is a sphingomyelinase causing lysis of ovine and bovine erythrocytes (Larsen et al. 2002).

Currently, the coagulase-negative staphylococci (CNS) are the most prevalent bacteria isolated from milk samples from cows in many modern dairy herds in several regions of the globe (Pyörälä and Taponen 2009). CNS strains isolated from milk of cows with mastitis produced proteases and haemolysins (Zhang and Maddox 2000, Bochniarz and Wawron 2012). Moreover, biofilm formation has been proposed as an important virulence factor of CNS, by which mastitis-causing staphylococci avoid the immune response of the cow and cause persistent intramammary infections (Simojoki et al. 2012). Although many researches recently have shown the importance of CNS in the bovine mastitis, the virulence factors of CNS remain poorly understood. Moreover, there are few studies that have compared the virulence factors of staphylococci isolated from case of bovine mastitis and other sources (Thorberg et al. 2006).

The aim of this study was to determine phenotypic virulence factors and the ability of $S$. aureus and different CNS species isolated from milk of cows with mastitis to form biofilm, and to compare them with virulence factors of staphylococci from milk of cows without mastitis and cowshed environment.

\section{Materials and Methods}

\section{Staphylococcal isolates}

A total of 172 staphylococcal strains from milk of cows with clinical and subclinical mastitis, 42 isolates from milk samples from cows without mastitis symptoms, as well as 37 isolates from cowshed environment, were used in this study. The strains from cows without mastitis symptoms and from cowshed environment were used for comparison purposes. The quarter milk samples and the samples from the cowshed environment (the swabs from teats skin, milker's hands, samples of cow's beddings, fodder and water) were collected in the eastern part of the Mazovia and the north Lublin region of Poland between February 2009 and March 2010. The sampling methods, isolation and identification of staphylococcal isolates were described previously (Kot et al. 2012a).

\section{Haemolysis activity and enzymes production}

The plates with 5\% sheep blood agar (Graso, Poland) were streaked with a fresh culture $\left(24 \mathrm{~h}\right.$ at $37^{\circ} \mathrm{C}$ in Brain Heart Infusion Broth) (BHI; BBL, Becton Dickinson, Sparks, $\mathrm{Md}$.) and incubated at $37^{\circ} \mathrm{C}$ for 24 to 48 hours. The haemolytic activity was examined after this period, according to the procedure described by Konemam et al. (1997). Protease activity was tested on casein agar plates, according to the procedure described by Bjorklind and Arvidson (1977). The esterase production was determined on the agar plates containing $0.1 \%$ Tween 80 and calcium chloride which were streaked with a fresh culture of staphylococci (24 h at $37^{\circ} \mathrm{C}$ in BHI broth) and incubated at $30^{\circ} \mathrm{C}$ for 7 days. The reading was carried out after this period. A white precipitate around the growth was a positive result (Soares et al. 2011). DNase activity was examined on DNase agar (BBL, Becton Dickinson). Staphylococcal strains were streaked on DNase agar and incubated at $37^{\circ} \mathrm{C}$ for 24 to 48 hours. After that, $1 \mathrm{~N} \mathrm{HCl}$ was poured on the plates and the presence of clear zone around the growth was regarded as a positive results (Gündoğan et al. 2006).

\section{Biofilm formation assay}

The ability of staphylococcal strains from milk samples from cows with- and without mastitis symptoms to form biofilm were examined. The biofilm assay was performed as described by Stepanović et al. (2000) with some modifications. Stationary growth phase bacterial cultures $(25 \mu \mathrm{l})$ were transferred aseptically to wells of a tissue culture polystyrene 96-well plate (Nunclon, Roskilde, Denmark), containing 175 $\mu$ of Tryptic-Soy Broth (TSB; BBL, Becton Dickinson). Biofilms were developed for $48 \mathrm{~h}$ at $37^{\circ} \mathrm{C}$. The growth medium was removed after $24 \mathrm{~h}$ and replaced. After $48 \mathrm{~h}$ the cultures were removed, each well was washed with PBS. Biofilm was fixed with $95 \%$ methanol and stained with $1 \%$ crystal violet (Sigma-Aldrich, Steinheim, Germany), washed with PBS and air dried. Colorant was solved in $96 \%$ ethanol to measure absorbance at $492 \mathrm{~nm}$ in microplate reader (model 550, Bio-Rad, USA). In each plate three wells were used as blanks containing medium. Strains were classified into four categories: no biofilm producer, weak, moderate and strong biofilm producer. All assays were performed in triplicate and the results were averaged. 
Table 1. Prevalence of virulence factors among staphylococcal strains isolated from the milk of cows with and without mastitis and the cowshed environment.

\begin{tabular}{|c|c|c|c|c|c|c|}
\hline \multirow{3}{*}{ Species (no.) } & \multirow{3}{*}{ Source of strains (no.) } & \multicolumn{5}{|c|}{ Frequency $(\%)$ of isolates producing: } \\
\hline & & \multicolumn{2}{|c|}{ Haemolysins } & \multicolumn{3}{|c|}{ Enzymes } \\
\hline & & $\alpha$ & $\beta$ & DNase & Esterase & Proteases \\
\hline \multirow[t]{2}{*}{ S. aureus (34) } & Cows with mastitis (33) & 72.7 & 21.2 & 90.9 & 42.4 & 48.5 \\
\hline & Cows without mastitis (1) & 100 & & 100 & & \\
\hline \multirow[t]{3}{*}{ S. xylosus (91) } & Cows with mastitis (58) & 8.6 & 53.4 & 12.1 & 12.1 & 22.4 \\
\hline & Cows without mastitis (9) & 22.2 & 11.1 & 11.1 & 22.2 & 33.3 \\
\hline & Cowshed samples (24) & 8.3 & & & 8.3 & \\
\hline \multirow[t]{3}{*}{ S. sciuri (36) } & Cows with mastitis (24) & 4.1 & 12.5 & 62.5 & 12.5 & 79.2 \\
\hline & Cows without mastitis (4) & & & 25 & & 25 \\
\hline & Cowshed samples (8) & & & 75 & 25 & 87.5 \\
\hline \multirow[t]{3}{*}{ S. epidermidis (31) } & Cows with mastitis (20) & 5 & 55 & & 70 & 35 \\
\hline & Cows without mastitis (10) & & 80 & 30 & 90 & 30 \\
\hline & Cowshed samples (1) & & & & 100 & 100 \\
\hline \multirow[t]{2}{*}{ S. simulans (6) } & Cows with mastitis (3) & & 33.3 & 33.3 & 66.6 & \\
\hline & Cows without mastitis (3) & & & 100 & 100 & 100 \\
\hline \multirow[t]{2}{*}{ S. lentus (4) } & Cows with mastitis (3) & & & 33.3 & & 66.6 \\
\hline & Cows without mastitis (1) & & & & & \\
\hline \multirow[t]{3}{*}{ Staphylococcus spp. (49) } & Cows with mastitis (31) & 32.2 & 48.4 & 9.7 & 29 & 25.8 \\
\hline & Cows without mastitis (14) & 21.4 & 50 & & 14.3 & 14.3 \\
\hline & Cowshed samples (4) & & & & 50 & \\
\hline
\end{tabular}

Table 2. Haemolytic activity and production of enzymes by $S$. aureus and the most numerous of CNS species isolated from milk of cows with and without mastitis and the cowshed environment.

\begin{tabular}{|c|c|c|c|c|c|c|c|c|c|c|}
\hline \multirow{3}{*}{ Virulence factors } & \multicolumn{10}{|c|}{ No. of isolates producing haemolysins and enzymes: } \\
\hline & \multicolumn{3}{|c|}{ S. aureus $(\mathrm{n})$} & \multicolumn{3}{|c|}{ S. xylosus (n) } & \multicolumn{4}{|c|}{ S. sciuri (n) } \\
\hline & $\begin{array}{c}\mathrm{A} \\
(33)\end{array}$ & $\begin{array}{c}\text { B } \\
(1)\end{array}$ & $\begin{array}{c}\text { A } \\
(58)\end{array}$ & $\begin{array}{l}\text { B } \\
(9)\end{array}$ & $\begin{array}{c}\mathrm{C} \\
(24)\end{array}$ & $\begin{array}{c}\chi_{\text {emp. }}^{2} \\
\text { comparison of: }\end{array}$ & $\begin{array}{c}\text { A } \\
(24)\end{array}$ & $\begin{array}{l}\text { B } \\
(4)\end{array}$ & $\begin{array}{c}C \\
(8)\end{array}$ & $\begin{array}{c}\chi_{\text {emp. }}^{2} \\
\text { comparison of: }\end{array}$ \\
\hline Haemolysins & 31 & 1 & 36 & 3 & 2 & $\begin{array}{c}19.71^{* *} \\
(\mathrm{~A} \text { and } \mathrm{C})\end{array}$ & 4 & - & - & - \\
\hline DNase & 30 & - & 7 & 1 & - & - & 15 & 1 & 6 & - \\
\hline Proteases & 16 & - & 13 & 3 & - & - & 19 & 1 & 7 & $\begin{array}{c}4.93^{*} \\
(\mathrm{~A} \text { and } \mathrm{B})\end{array}$ \\
\hline Esterase & 14 & - & 7 & 1 & 2 & - & 3 & - & 2 & - \\
\hline
\end{tabular}

A - strains from milk samples from cows with mastitis, B - strains from milk samples from cows without mastitis symptoms,

$\mathrm{C}$ - strains from the cowshed environment.

* The significant relationship between the number of strains producing proteases and the source of isolation.

** The highly significant relationship between the number of strains producing haemolysins and the source of isolation.

\section{Statistical analyses}

Chi-square statistics in Statistix 8.0 (Analytical Software, Tallahassee, FL, USA) was used for calculations in order to determine the dependence between the source of staphylococci isolation and the production of hemolysins and enzymes by these isolates. Adhesion of different staphylococci to polystyrene was compared by using Kruskal-Wallis test. Chi-square test at $\mathrm{p} \leq 0.05$ was used for detailed comparisons of ranks average for adhering to polystyrene of different Staphylococcus species. Ranks for which the difference in absolute value was greater than $\chi_{\text {emp }}^{2}=23.7$, were regarded as significantly different. 


\section{Results}

The haemolytic activity, production of DNase, proteases, esterase and biofilm formation were investigated in 251 strains including 34 S. aureus and 217 CNS originating from milk of cows with clinical or subclinical mastitis, from the milk of cows without mastitis and from the cowshed environment. Most of S. aureus strains from cows with mastitis showed haemolytic activity (93.9\%), among them $72.7 \%$ and $21.2 \%$ produced $\alpha$ - and $\beta$-haemolysin, respectively. Above $48 \%$ of $S$. aureus from cows with mastitis symptoms produced proteases and $42.4 \%$ of these strains produced esterase. S. aureus from cows without mastitis did not produce esterase and proteases (Table 1). Among the most frequently isolated species of CNS were $S$. xylosus, S. sciuri and S. epidermidis. The haemolytic activity was observed in $62 \%$ S. xylosus strains isolated from milk of cows with mastitis, and among them strains produced $\alpha$-haemolysin (8.6\%) and $\beta$-haemolysin (53.4\%) were found (Table 1). S. xylosus strains from the cowshed environment did not produce DNase or proteases. The highest frequency of CNS strains producing DNase and proteases was found for S. sciuri. Most of S. epidermidis and Staphylococcus spp. from cows with and without mastitis showed the haemolytic activity. The esterase was produced by most of the $S$. epidermidis and $S$. simulans (Table 1 ).

The number of $S$. xylosus strains with haemolytic activity $(n=36)$ was the highest among the strains from milk of cows with mastitis and it was significantly associated with their origin (value of $\chi^{2}$ emp equal to 19.71). The ability to produce proteases was significantly associated with $S$. sciuri from milk of cows with mastitis (value of $\chi_{\text {emp }}^{2}$ equal to 4.93) (Table 2).

Based on the amount of crystal violet bound by the biofilm, the ability of staphylococci to form a biofilm was investigated by measuring absorbance at $492 \mathrm{~nm}$. The average absorbance for adhering staphylococci from milk of cows with mastitis was significantly higher than the average absorbance obtained in the case of adhering staphylococci isolated from milk of cows without mastitis $(p \leq 0.05)$ (Fig. 1). The most frequent strains from milk of cows with mastitis were weak biofilm formers (48.6\%), while $40 \%$ and $11.4 \%$ of strains were moderate and strong biofilm formers, respectively. Strains showing strong adhesion belonged to $S$. xylosus, $S$. sciuri and $S$. simulans species. Most of strains from milk of cows without mastitis showed weak adhesion (77.3\%). Other strains from this group were moderate biofilm formers.

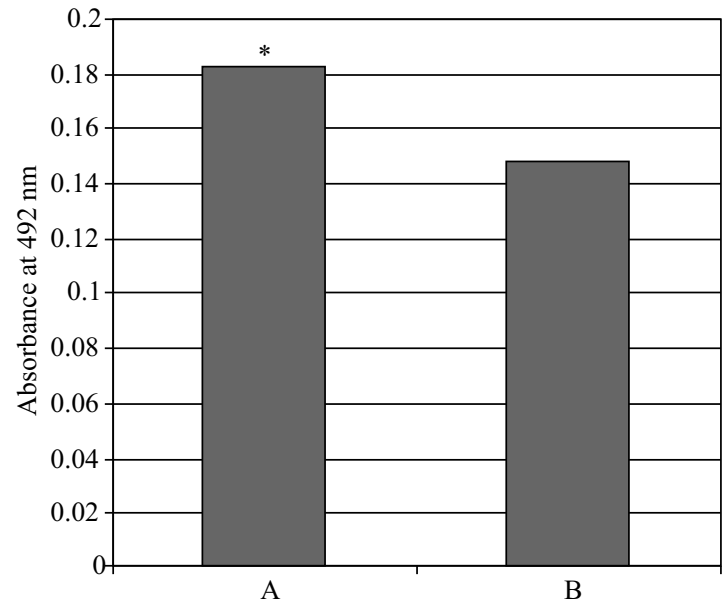

Fig. 1. The ability of forming biofilm by the Staphylococcus from milk of cows with and without mastitis.

Columns show the mean absorbance obtained for strains from two sources of isolation which formed biofilm on polystyrene. The mean absorbance was calculated on the basis of he experiment performed in three replicates.

*, the adhesion of staphylococcal strains from milk of cows with mastitis to polystyrene was significantly higher than in strains from milk of cows without mastitis $(p \leq 0.05)$.

A - staphylococci from milk of cows with mastitis, B - staphylococci from milk of cows without mastitis.

Among the dominant staphylococcal species, S. xylosus showed significantly higher ability to form biofilm compared to other species $(\mathrm{p} \leq 0.05)$ (Fig. 2). The mean absorbance for biofilm formed by $S$. sciuri was significantly lower than for biofilm formed by $S$. xylosus but significantly higher than for biofilm formed by $S$. epidermidis and $S$. aureus. The lowest ability to form biofilm was observed in $S$. aureus but the mean absorbance for this species did not significantly differ from the mean absorbance obtained for $S$. epidermidis.

\section{Discussion}

Staphylococci are the microorganisms most frequently isolated from bovine mastitis cases and are considered the most important etiological agents for this infection (Malinowski et al. 2006, Sawant et al. 2009, Kot et al. 2012a,b, Simojoki et al. 2012). S. aureus has been considered the major pathogen but, currently, CNS are also frequently isolated from milk samples in many modern dairy herds where efficient mastitis control protocols are implemented (Gillespie et al. 2009, Sampimon et al. 2009).

The pathogenicity of staphylococci is related to the production of several virulence factors responsible for the development of disease process (Taponen and Pyorala 2009, Soares et al. 2011). Various virulence 


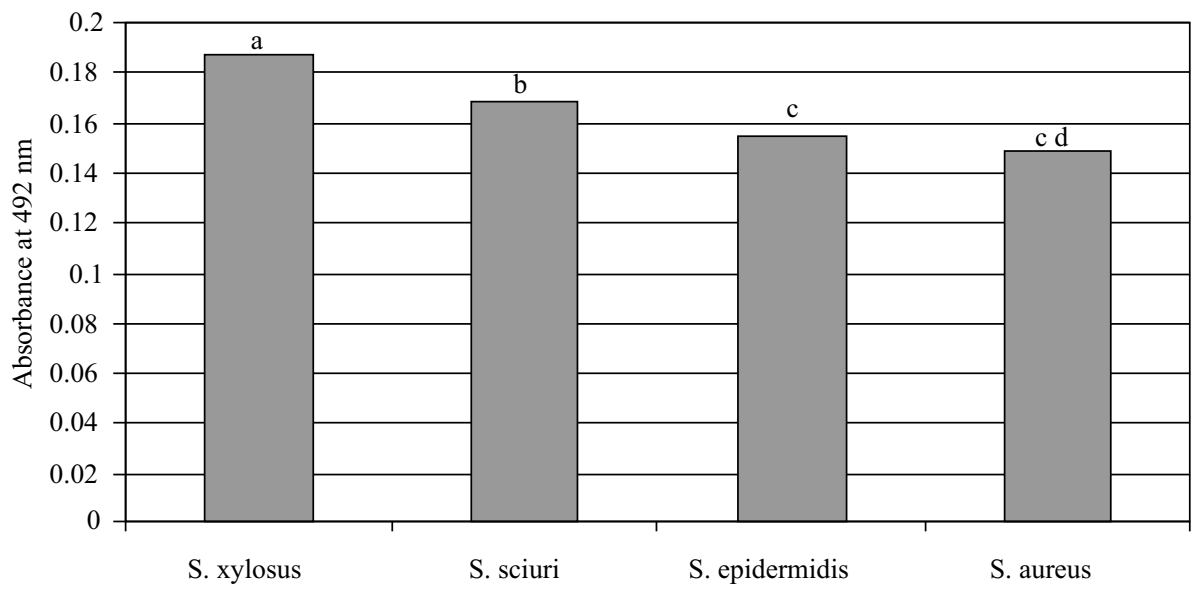

Fig. 2. The ability of forming biofilm by the dominant Staphylococcus species.

Columns show the mean absorbance obtained for biofilm formed on polystyrene by different Staphylococcus species. The designation of columns with different letters indicates that adhesion differ significantly at $\mathrm{p} \leq 0.05$. The designation of columns with the same letters indicates that adhesion was not significantly different at $p \leq 0.05$.

factors were found in $S$. aureus strains isolated from bovine mastitis (Silva et al. 2005, Hata et al. 2006, Peles et al. 2007, Melchior et al. 2009, Capurro et al. 2010), but only few studies involved search of virulence factors of CNS isolated from bovine mastitis (Zhang and Maddox 2000, Bochniarz and Wawron 2012). Virulence factors of staphylococci have been investigated by measuring phenotypic expression of products associated with virulence (Taponen and Pyörälä 2009). In this study, we compared the production of haemolysins, DNase, esterase and proteases by $S$. aureus and CNS strains isolated in the central region of Poland from milk of cows with mastitis and without mastitis and the cowshed environment. The ability to form of biofilm by staphylococci from milk of cows with mastitis and without mastitis were also determined.

Haemolysins are identified as important virulence factors that belong to cytolytic exotoxins affecting the cell membrane. Staphylococci produce several types of haemolysins, facilitating the access to iron contained in haemoglobin by degradation of erythrocyte cell membranes (Salyers and Whitt 1994).

In our study, most of $S$. aureus strains showed haemolytic activity which is consistent with the results obtained by other authors (Capurro et al. 2010). In the CNS group, the percentage of strains with haemolytic activity was highest among $S$. xylosus from mastitis $(62 \%)$ and this feature was significantly associated with this source of isolation. However, only $8.3 \%$ S. xylosus from cowshed samples showed haemolytic activity. The high number of CNS isolated from intramammary infection demonstrating haemolytic activity was showed by Silva et al. (2005), among them also $S$. xylosus produced haemolytic zone. Watts and Owens (1987) observed haemolysin production by $S$. xylosus and $S$. sciuri. In our study, only some strains of $S$. sciuri from cows with mastitis showed haemolytic activity. We have observed that $S$. sciuri strains from the milk samples from cows with mastitis symptoms produced proteases (above 79\%) and DNase (above 62\%), and the percentage of strains with these activities was higher than that of $S$. sciuri strains from the milk samples of cows without mastitis. Stepanović et al. (2001) also showed strong proteolytic and DNase activities in 121 human and animal S. sciuri isolates. Zhang and Maddox (2000) stated that cytotoxic activity and casein hydrolysis activity of CNS from bovine mastitis was associated with production of 34- to $36-\mathrm{kDa}$ protein. In this study, we also investigated esterase activity and we found the highest percentage of strains with this activity among S. epidermidis.

Biofilm formation has been proposed as an important virulence factor of $S$. aureus and CNS, especially with regard to the persistence of CNS intramammary infection (Melchior et al. 2011, Simojoki et al. 2012). In this study, a strong relationship between the strength of biofilm and source of strains was noted. The staphylococcal strains isolated from milk of cows with mastitis had a greater ability to form biofilm than strains isolated from milk of cows without mastitis. However, our results revealed that only few of CNS strains isolated from mastitis were strong biofilm formers which is in agreement with the results obtained by Simojoki et al. (2012). Most of strains from milk of cows without mastitis showed weak ability to form biofilm.

Information on the biofilm formation by CNS species associated with the cases of mastitis is limited. 
In the present study, the ability to form biofilms were different among CNS species and we found that $S$. xylosus had the greatest ability to form biofilm. This observations confirm the report by Tremblay et al. (2013) who showed that $S$. xylosus isolates associated with mastitis had the highest ability to produce biofilm. The same authors also showed that $S$. epidermidis had the lowest ability to form biofilms and this was confirmed by our results. We have also observed that $S$. aureus had a little ability to form biofilm, which was not significantly different from $S$. epidermidis. In our study, most of $S$. aureus strains were weak biofilm formers, contrary to the results obtained by Dhanawade et al. (2010) who reported strong and moderate biofilm production by these bacteria. On the other hand, Vasudevan et al. (2003) showed that the strains of $S$. aureus varied in their biofilm forming ability on tissue culture plates and that out of the 35 mastitis $S$. aureus strains only 24 produced biofilm.

Our results indicate that haemolytic activity and production of proteases were significantly associated with $S$. xylosus and S. sciuri, respectively, which were isolated from cows with mastitis. The species of Staphylococcus differed in ability to form of biofilm. The ability of biofilm formation by staphylococcal strains from milk of cows with mastitis was greater than in strains from milk of cows without mastitis.

It is suggested that the virulence factors such as production of exotoxins, enzymes and formation of biofilm are important in pathogenesis of mastitis.

\section{References}

Bjorklind A, Arvidson S (1977) Occurrence of an extracellular serine proteinase among Staphylococcus aureus strains. Acta Pathol Microbiol Scand B 85: 277-280.

Bochniarz M, Wawron W (2012) Haemolytic and proteolytic activity of coagulase-negative staphylococci isolated from mastitis cows. Pol J Vet Sci 15: 61-65.

Capurro A, Aspän A, Artursson K, Waller KP (2010) Genotypic variation among Staphylococcus aureus isolates from cases of clinical mastitis in Swedish dairy cows. Vet J 185: 188-192.

Da Silva ER, Boechat JU, Martins JC, Ferreira WP, Siqueira AP, da Silva N (2005) Hemolysin production by Staphylococcus aureus species isolated from mastitis goat milk in Brazilian dairy herds. Small Rumin Res 56: 271-275.

Dhanawade NB, Kalorey DR, Srinivasan R, Barbuddhe SB, Kurkure NV (2010) Detection of intercellular adhesion genes and biofilm production in Staphylococcus aureus isolated from bovine subclinical mastitis. Vet Res Commun 34: 81-89.

Dinges MM, Orwin PM, Schlievert PM (2000) Exotoxins of Staphylococcus aureus. Clin Microbiol Rev 13: 16-34.

Gillespie BE, Headrick SI, Boonyayatra S, Oliver SP (2009) Prevalence and persistence of coagulase-negative
Staphylococcus species in three dairy research herds. Vet Microbiol 134: 65-72.

Gündoğan N, Citak S, Turan E (2006) Slime production, DNase activity and antibiotic resistance of Staphylococcus aureus isolated from raw milk, pasteurised milk and ice cream samples. Food Control 17: 389-392.

Hata E, Katsuda K, Kobayashi H, Ogawa T, Endô T, Eguchi $M$ (2006) Characteristics and epidemiologic genotyping of Staphylococcus aureus isolates from bovine mastitic milk in Hokkaido, Japan. J Vet Med Sci 68: 165-70.

Konemam EW, Allen SD, Janda WM, Schreckenberger PC, Winn Jr WC (1997) Color Atlas and Textbook of Diagnostic Microbiology, 5th ed., Lippincott-Raven Pulishers, Philadelphia.

Kot B, Piechota M, Antos-Bielska M, Zdunek E, Wolska KM, Binek T, Olszewska J, Guliński P, Trafny EA (2012a) Antimicrobial resistance and genotypes of staphylococci from bovine milk and the cowshed environment. Pol J Vet Sci 15: 741-749.

Kot B, Piechota M, Wolska KM, Frankowska A, Zdunek E, Binek T, Kłopotowska E, Antosiewicz M (2012b) Phenotypic and genotypic antimicrobial resistance of staphylococci from bovine milk. Pol J Vet Sci 15: 677-683.

Larsen HD, Aarestrup FM, Jensen NE (2002) Geographical variation in the presence of genes encoding superantigenic exotoxins and beta-hemolysin among Staphylococcus aureus isolated from bovine mastitis in Europe and USA. Vet Microbiol 85: 61-67.

Malinowski E, Lassa H, Kłossowska A, Smulski S, Markiewicz H, Kaczmarowski M (2006) Etiological agents of dairy cows' mastitis in western part of Poland. Pol J Vet Sci 9: 191-194.

Melchior MB, van Osch MH, Graat RM, van Duijkeren E, Mevius DJ, Nielen M, Gaastra W, Fink-Gremmels J (2009) Biofilm formation and genotyping of Staphylococcus aureus bovine mastitis isolates: evidence for lack of penicillin-resistance in $A g r$-type II strains. Vet Microbiol 137: 83-89.

Melchior MB, van Osch MH, Lam TJ, Vernooij JC, Gaastra W, Fink-Gremmels J (2011) Extended biofilm susceptibility assay for Staphylococcus aureus bovine mastitis isolates: evidence for association between genetic makeup and biofilm susceptibility. J Dairy Sci 94: 5926-5937.

Peles F, Wagner M, Varga L, Hein I, Rieck P, Gutser K, Keresztúri P, Kardos G, Turcsányi I, Béri B, Szabó A (2007) Characterization of Staphylococcus aureus strains isolated from bovine milk in Hungary. Int J Food Microbiol 118: 186-93.

Pyörälä S, Taponen S (2009) Coagulase-negative staphylococci - emerging mastitis pathogens. Vet Microbiol 134: 3-8.

Salyers AA, Whitt DD (1994) Bacterial pathogenesis: A molecular approach. Washington, DC: ASM Press.

Sampimon OC, Barkema HW, Berends IM, Sol J, Lam TJ (2009) Prevalence and herd-level risk factors for intramammary infection with coagulase-negative staphylococci in Dutch dairy herds. Vet Microbiol 134: 37-44.

Sawant AA, Gillespie BE, Oliver SP (2009) Antimicrobial susceptibility of coagulase-negative Staphylococcus species isolated from bovine milk. Vet Microbiol 134: 73-81.

Simojoki H, Hyvönen P, Plumed Ferrer C, Taponen S, Pyörälä $S$ (2012) Is the biofilm formation and slime 
producing ability of coagulase-negative staphylococci associated with the persistence and severity of intramammary infection? Vet Microbiol 158: 344-352.

Soares, JC, Marques MR, Tavaria FK. Pereira JO, Malcata FX, Pintado MM (2011) Biodiversity and characterization of Staphylococcus species isolated from a small manufacturing dairy plant in Portugal. Int J Food Microbiol 146: 123-129.

Stepanović S, Vuković D, Dakić I, Savić B, Švabić-Vlahović M (2000) A modified microtiter-plate test for quantification of staphylococcal biofilm formation. J Microbiol Methods 40: 157-179.

Stepanović S, Vukovicć D, Trajković V, Samardzić T, Cupić M, Svabić-Vlahović M (2001) Possible virulence factors of Staphylococcus sciuri. FEMS Microbiol Lett 199: 47-53.

Taponen S, Pyörälä S (2009) Coagulase-negative staphylococci as cause of bovine mastitis-not so different from Staphylococcus aureus? Vet Microbiol 134: 29-36.
Thorberg BM, Kühn I, Aarestrup FM, Brändström B, Jonsson P, Danielson-Tham ML (2006) Pheno- and genotyping of Staphylococcus epidermidis isolated from bovine milk and human skin. Vet Microbiol 115: 163-172.

Tremblay YD, Lamarche D, Chever P, Haine D, Messier S, Jacques M (2013) Characterization of the ability of coagulase-negative staphylococci isolated from the milk of Canadian farms to form biofilms. J Dairy Sci 96: 234-246.

Vasudevan P, Nair MK, Annamalai T, Venkitanarayanan KS (2003) Phenotypic and genotypic characterization of bovine mastitis isolates of Staphylococcus aureus for biofilm formation. Vet Microbiol 92: 179-185.

Watts JL, Owens WE (1987) Synergistic hemolysis associated with coagulase-negative staphylococci isolated from bovine mammary glands. J Clin Microbiol 25: 2037-2039.

Zhang S, Maddox CW (2000) Cytotoxic activity of coagulase-negative staphylococci in bovine mastitis. Infect Immun 68: 1102-1108. 